\title{
Modified zinc phosphate coatings: a promising approach to enhance the anti-corrosion properties of reinforcing steel
}

\begin{abstract}
Zinc phosphate conversion coatings are widely used for increasing corrosion resistance and surface preparation for painting. This kind of treatment has recently been introduced in the field of reinforced concrete. However, the disadvantage in the use of such coatings is the existence of pores. Zinc phosphating baths have constantly been developed and modified by additives in order to enhance the coating characteristics including the corrosion resistance and the alkaline stability. These additives and their effects on the resulting coating were reviewed in the current paper. The mechanism of phosphate coating formation, the alkali stability of the coating and the disposal of the phosphating sludge were also briefly reviewed.
\end{abstract}

Keywords: zinc phosphate coating, reinforcing steel, corrosion of reinforcement, phosphating bath additives, concrete
Volume 3 Issue 5 - 2017

\author{
Aref $M$ al-Swaidani \\ Faculty of Architectural Engineering, Arab International \\ (Formerly European) University, Syria
}

Correspondence: Aref A al-Swaidani, Associate Professor, Faculty of Architectural Engineering, Arab International (Formerly European) University, Damascus, Syria, Email a-swaidan@gmail.com; a-swaidani@aiu.edu.sy

Received: June 07, 2017| Published: December 07, 2017

\section{Introduction}

Reinforcing steel embedded in fresh concrete develops a protective passive layer on its surface. This layer, which is formed as result of high alkalinity of the concrete pore solution $(\mathrm{pH} / 13)$, consists of $\gamma-\mathrm{Fe}_{2} \mathrm{O}_{3}$ adhering tightly to the steel. As long as that oxide film is present, the steel remains intact. ${ }^{1}$ However, chloride ions attack and concrete carbonation can destroy the film and, in the presence of $\mathrm{H}_{2} \mathrm{O}$ and $\mathrm{O}_{2}$ reinforcement corrosion takes place. Chloride ions, which were described by Verbeck ${ }^{2}$ as the specific and unique destroyer, can be present in concrete either through the use of contaminated aggregate, sea water, brackish water or admixtures containing chlorides. ${ }^{1}$ In the literature, there are state of the art review studies on numerous methods of protection against reinforcement corrosion..$^{3-8}$ Applying zinc phosphate coating on reinforcing steel will probably be a vital approach in the future. ${ }^{9-14}$ The phospahting process has been known for over a century. ${ }^{15}$ It was extensively used in the automobile and appliance industries. ${ }^{16,17}$ This treatment primarily provides an inexpensive, ${ }^{17,18}$ non-toxic, ${ }^{19,20}$ reasonably hard, highly adherent and electronically non-conducting phosphate coating. ${ }^{15}$ The insulation properties make an important contribution to the prevention of reinforcement corrosion. ${ }^{14}$ Further, the phosphate conversion coatings are currently considered eco-friendly. ${ }^{21}$ However, Phosphate coatings usually contain pores which are pathways for the corrosive electrolyte diffusion into the metal substrate. As a result, the corrosion resistance of the conventional phosphate coating is not high enough. Additives such as $\mathrm{Ni}^{2+}, \mathrm{Ca}^{2+}, \mathrm{Mo}^{2+}, \mathrm{Cu}^{2+}$ and $\mathrm{Mn}^{2+}$ and nanoparticles have been extensively used to produce phosphate coatings with uniform structure, lower porosity and improved corrosion resistance and adhesion properties. ${ }^{22,13,12,23,11,17,24}$ Being a newly adapted method in the field of reinforcement corrosion protection ${ }^{25-27,13}$ this paper tries to review some important aspects related to the improvement of corrosion resistance of reinforcement using zinc phosphate coatings modified by metal cat ions or nanoparticles.

\section{Mechanism of zinc phosphate coating formation}

Phosphating is essentially an electrochemical process. ${ }^{28}$ When the steel comes into contact with phosphate solution which is basically a phosphoric acid-based solution, an electrochemical reaction takes place where $\mathrm{Fe}^{2+}$ start to dissolve and release electrons at the anodic site, and the reduction of $\mathrm{H}^{+}$occurs at the cathodic site. The evolution of hydrogen and consumption of $\mathrm{H}^{+}$ions results in a local increase of $\mathrm{pH}$ at the surface leading to precipitation of zinc phosphate crystals. ${ }^{29}$ According to Zimmermann, ${ }^{23}$ Donofrio $^{30}$ and Kunst, ${ }^{31}$ the possible reactions taking place in the zinc phosphating bath are as follows:

$$
\begin{gathered}
3 \mathrm{Zn}^{2+}+2 \mathrm{H}_{2} \mathrm{PO}_{4}^{-}+4 \mathrm{H}_{2} \mathrm{O} \rightarrow \mathrm{Zn}_{3}\left(\mathrm{PO}_{4}\right)_{2} \cdot 4 \mathrm{H}_{2} \mathrm{O}(\text { Hopeite })+4 \mathrm{H}^{+} \\
2 \mathrm{Zn}^{2+}+\mathrm{Fe}^{2+}+2 \mathrm{H}_{2} \mathrm{PO}_{4}^{-}+4 \mathrm{H}_{2} \mathrm{O} \rightarrow \mathrm{Zn}_{2} \mathrm{Fe}\left(\mathrm{PO}_{4}\right)_{2} \cdot 4 \mathrm{H}_{2} \mathrm{O}(\text { Phosphophyllite })+4 \mathrm{H}^{+}
\end{gathered}
$$

In general, the presence of phosphophyllite is associated with a better corrosion resistance than hopeite, probably due to its enhanced chemical stability relative to alkaline electrolytes. ${ }^{32}$

\section{Alkaline stability of zinc phosphate coating}

Studying the alkaline stability of zinc-phosphated reinforcing steel is of great importance, as it will be embedded in a highly alkaline 
environment ( $\mathrm{pH} \sim 13)$. There are few published studies on the alkaline stability of the phosphate coating on reinforcing steel. Literature shows that the alkaline stability of zinc phosphate coatings depends on their chemical composition and crystal structure. ${ }^{33}$ Hopeite $\left(\mathrm{Zn}_{3}\left(\mathrm{PO}_{4}\right)_{2} \cdot 4 \mathrm{H}_{2} \mathrm{O}\right)$ has a higher alkaine solubility than phosphophyllite $\left(\mathrm{Zn}_{2} \mathrm{Fe}\left(\mathrm{PO}_{4}\right)_{2} \cdot \mathrm{H}_{2} \mathrm{O}\right){ }^{30,34,35}$ Thus, alkaline solutions first dissolve the coating composed of hopeite. Then the dissolution continues for layers rich in iron and those mainly composed of phosphophyllite. ${ }^{36}$ According to the study of Simescu \& Idrissi, ${ }^{13}$ the dissolution of zinc phosphate coating in the alkaline medium $(\mathrm{pH} 12.5)$ is accompanied by the formation of hydroxyapatite $\mathrm{Ca}_{10}\left(\mathrm{PO}_{4}\right)_{6}(\mathrm{OH})_{2}$. Hydroxyapatite formation occurs even in the presence of aggressive chloride ions ${ }^{13}$ Figure 1. This chemical compound provides an effective protection against reinforcement corrosion and contributes to the reduction in chloride aggressiveness. ${ }^{10}$ Elshami ${ }^{9}$ reported that the phosphated steel was more resistant than non-phosphated steel when exposed to alkaline solutions even in the presence of chloride ions. They attributed this behavior to the formation of a dense and protective layer composed of calcium hydroxyzincate $\left(\mathrm{Ca}\left(\mathrm{Zn}(\mathrm{OH})_{3}\right)_{2} \cdot 2 \mathrm{H}_{2} \mathrm{O}\right)$ which caused passivation of steel in concrete, thus contributing to a decrease in the aggressiveness of chlorides.
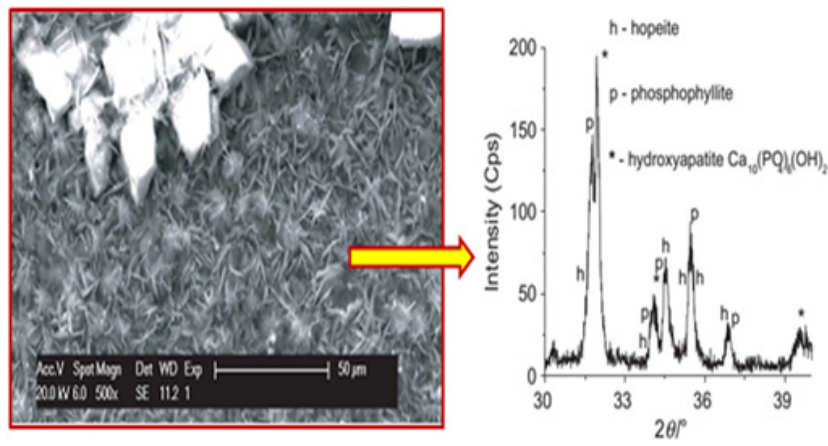

Figure I Scanning Electron Micrograph (SEM) of phosphated mild steel after 8 immersion days in a solution of saturated lime containing 35 g.L-I NaCl (left) and X-ray diffraction pattern of the studied area (right). ${ }^{10}$

\section{Effects of additives (cations, nanoparticles) on the properties of zinc phosphate coating}

Different kinds of additives have been employed in the phosphating bath to improve properties of the phosphate coating. Numerous studies have explored the effects of these additives on the performance of zinc phosphate coatings. Some of these additives are metal cations such as $\mathrm{Ni}^{2+}, \mathrm{Ca}^{2+}, \mathrm{Mn}^{2+}, \mathrm{Cu}^{2+}$ and $\mathrm{Mo}^{2+}$, and nanoparticles like nano$\mathrm{SiO}_{2}{ }^{11,17,21}$ nano-TiO 2 Shibli \& Chacko, ${ }^{37}$ nano- $\mathrm{ZnO}^{38}$ and nano$\mathrm{CeO}_{2} \cdot{ }^{39}$ These additives have showed a great improvement to the final coating performance. They were also found to reduce the porosity of the phosphate conversion coating. ${ }^{40}$

Nickel addition: The addition of $\mathrm{Ni}^{2+}$ ions to the phosphating bath resulted in the modification of the crystalline form, Figure $2 .^{41}$ As clearly seen in Figure 2, zinc phosphate coating without $\mathrm{Ni}^{2+}$ addition is characterized by plates with sizes up to $30 \mathrm{~mm}$ in length and 10 $\mathrm{mm}$ in width, whereas the addition of $\mathrm{Ni}^{2+}$ significantly refined the crystals. This grain refinement was also reported in literature. ${ }^{42,43,9,32}$ In addition, $\mathrm{Ni}^{2+}$ played an important role in the nucleation process, probably through the ion exchange mechanism proposed by Tegehall \&
Vannerberg. ${ }^{44}$ Its presence also accelerated the surface reactions during phosphating ${ }^{30}$ and improved the corrosion resistance of steel..$^{45,23,46,10,14}$ As shown in Figure 3 \& Table 1, after 8 days of immersion in a saturated lime solution containing $35 \mathrm{~g} . \mathrm{L}^{1} \mathrm{NaCl}$ solution, $\mathrm{Ni}^{2+}$-modified zinc phosphate coating (PMS) showed a lower current density $(\approx$ onetenth) than mild steel (MS), and decreased the pitting susceptibility by increasing pitting potential at about $160 \mathrm{mV}$ compared with MS corrosion currents. ${ }^{10}$ Further, this addition improved the resistance of phosphate coating against the alkaline environment, ${ }^{13,34}$ i.e. $\mathrm{Ni}^{2+}$ ions increased the alkaline stability of phosphate layers. ${ }^{34,13}$ Satoh et al., ${ }^{47}$ studied the effects of heavy metal ion addition on zinc phosphating on electro galvanized steels and proposed the substitution of $\mathrm{Zn}^{2+}$ by $\mathrm{Ni}^{2+}$ in hopeite, such as $\mathrm{Zn}_{(3-\mathrm{x})} \mathrm{Ni}_{\mathrm{x}}\left(\mathrm{PO}_{4}\right)_{2} \cdot \mathrm{yH}_{2} \mathrm{In}$ a Su \& $\mathrm{Lin}^{40}$ study, the addition of $\mathrm{Ni}^{2+}$ in the phosphate solution promoted the impingement of $\mathrm{Ni}^{2+}, \mathrm{PO}_{4}^{3-}$, and $\mathrm{Zn}^{2+}$. Thereby, the nucleation of the phosphate conversion coating was promoted. Thus, the $\mathrm{Ni}^{2+}$ can accelerate the nucleation of $\mathrm{Zn}_{(3-\mathrm{x})} \mathrm{Ni}_{\mathrm{x}}\left(\mathrm{PO}_{4}\right)_{2} \cdot 4 \mathrm{H}_{2} \mathrm{O}$ grains (Figure 2). ${ }^{40}$ According to Kulinich \& Akhta, ${ }^{48} \mathrm{Ni}^{2+}$ has two main roles in the zinc phospate coating mechanism. First, the rate of increase in local solution $\mathrm{pH}$ is limited by the slower kinetics of reactions involving $\mathrm{Ni}^{2+}$ compared to $\mathrm{Zn}^{2+}$, leading to thinner zinc phosphate coatings when $\mathrm{Ni}^{2+}$ is present in the coating solution. Second, most $\mathrm{Ni}^{2+}$ deposition occurs during the later stages of the coating process, by nickel phosphate deposition and formation of a Ni-rich corrosion-resistant oxide (Figure $3 \&$ Table $1)$.
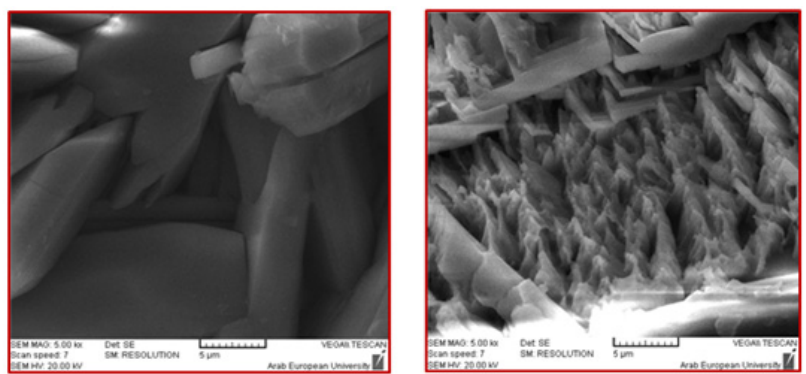

Figure 2 SEMs of the reinforcing steel samples treated in zinc phosphate bath (a) without $\mathrm{Ni}^{2+}$ and (b) containing $\mathrm{Ni}^{2+} .4$

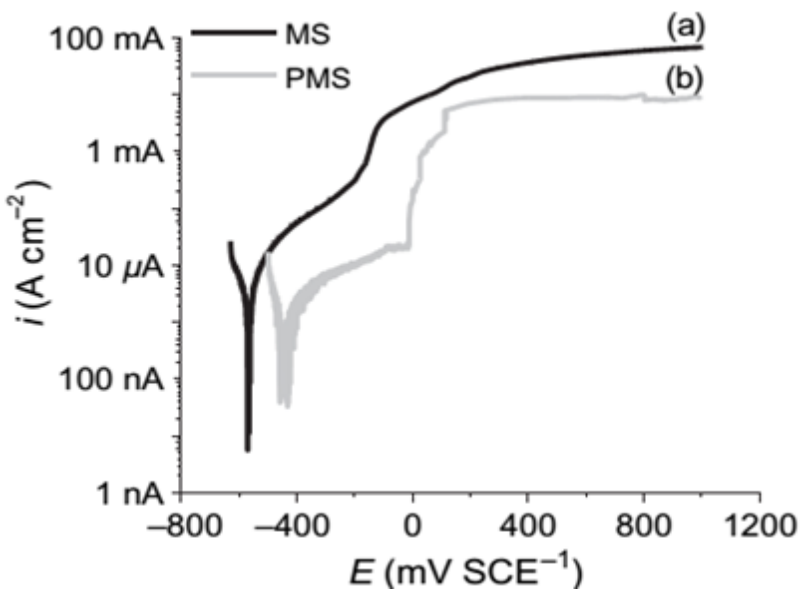

Figure 3 Polarization curves for mild steel (MS) and phosphate mild steel $\left(\mathrm{PMS}+\mathrm{Ni}^{2+}\right.$ ) after 8 days of immersion in a solution of saturated lime containing 35 g. L. ${ }^{-1} \mathrm{NaCl} .{ }^{10}$ 
Table I Corrosion potentials, current densities (at corrosion potential) and pitting potentials of MS and PMS samples after 8 days of immersion in SC solution ${ }^{10}$

\begin{tabular}{llll}
\hline Sample & $\mathbf{E}_{\text {corr }}\left(\mathbf{m V} \mathbf{E C S}^{-1}\right)$ & $\left.\mathbf{i}(\boldsymbol{\mu} \mathbf{A ~ c m})^{-2}\right)$ & $\mathbf{E}_{\mathrm{pit}}\left(\mathbf{m V} \mathbf{E C S}^{-1}\right)$ \\
\hline Mild steel (MS) & -570 & 20 & -180 \\
$\mathrm{Ni}^{2+}$ modified-Zinc Phosphated mild steel (PMS) & -460 & 2 & -20 \\
\hline
\end{tabular}

Calcium addition: Incorporation of calcium ions into zinc-phophate bath has resulted in considerable reduction in the grain size, more compact structure and better corrosion prevention ability. ${ }^{49,50} \mathrm{Jalili}^{12}$ showed that adding $\mathrm{Ca}^{2+}$ to the phosphate bath led to a significant reduction in corrosion current to a value of about one-fifth to oneeighth when compared to that recorded by the control. This addition also enhanced the bond strength between the rebar and the concrete by about $74 \%$. They explained this enhancement by the mechanical interlocking, which was the dominant mechanism. The zinc phosphate baths modified by calcium ions $\left(\mathrm{Ca}^{2+}\right)$ contain rhombic crystals of scholzite $\mathrm{Zn}_{2} \mathrm{Ca}\left(\mathrm{PO}_{4}\right)_{2} \cdot 2 \mathrm{H}_{2} \mathrm{O} .{ }^{28} \mathrm{Zeng}^{21}$ observed that adding calcium ions into the phosphate bath, the morphology changed from river-bedlike sheets to flower-type structure, which was more compact, crackfree and showed significant enhancement of anticorrosion properties.

Copper addition: Copper cations are basically used for their active role in the germination and growth of phosphate crystals. ${ }^{51,52}$ Copper also refined the crystal structure and enhanced the coverage of the surface significantly. ${ }^{53}$ This was attributed to the effect of CU-Fe galvanic couple on dissolution of iron and acceleration of crystal deposition. ${ }^{53}$ Leoni $^{54}$ revealed that the addition of copper to the phosphating bath led to a drastic reduction in the corrosion rate. Kulinich \& Akhtar ${ }^{48}$ reported that adding $\mathrm{Cu}^{2+}$ to the zinc phosphate coating bath at concentrations up to 10ppm caused significant changes in coating morphology, adhesion, and corrosion protection. Copper sometimes replaces nickel for environment-related reasons. Although copper is considered to have nearly the same toxicity as nickel, it can be used in much lower concentration in the phospahting bath. ${ }^{32}$ According to, ${ }^{32} \mathrm{Cu}^{2+}$ may deposit as copper metal on the surface. Therefore, the metal surface exposed between the crystals is, in fact, a surface of copper rather than the base metal..$^{32}$

Manganese addition: Manganese $\left(\mathrm{Mn}^{2+}\right)$ behavior, to some extent, in the phosphating bath is similar to that of $\mathrm{Ni}^{2+}$. The inclusion of $\mathrm{Mn}^{2+}$ into the phosphate bath resulted in more ordered structure and enhanced corrosion resistance properties. ${ }^{55,47}$ In addition, $\mathrm{Mn}^{2+}$ may replace $\mathrm{Zn}^{2+}$ in the hopeite crystal lattic. According to $\mathrm{Su} \& \mathrm{Lin},{ }^{40}$ the major role of $\mathrm{Mn}^{2+}$ in the phosphate treating solution is to enhance the impingement of $\mathrm{Mn}^{2+}, \mathrm{PO}_{4}^{3-}$, and $\mathrm{Zn}^{2+}$ in the solution and accelerating the formation of $\mathrm{Mn}_{2} \mathrm{Zn}\left(\mathrm{PO}_{4}\right)_{2} \cdot 4 \mathrm{H}_{2}$ Rezaee ${ }^{22}$ also observed this formation. However, contrary to the results related to the grain refinement effect accompanying with adding $\mathrm{Mn}^{2+}$, Rezaee ${ }^{22}$ observed a plate-like morphology on the sample treated by the phosphate coating containing $\mathrm{Mn}^{2+}$, Figure 4. This plate-like morphology of the phosphate crystals caused a higher surface coverage than needle like phosphate crystal. They showed that addition of $\mathrm{Mn}^{2+}$ to the phosphate bath solution caused an increase in phosphate crystal size. The competition between $\mathrm{Mn}^{2+}$ and $\mathrm{Zn}^{2+}$ cat ions to form phosphate complexes caused a decrease in the number of zinc phosphate crystals. As a result, the crystal size in the presence of $\mathrm{Mn}^{2+}$ became higher than that formed in the absence of the additive. In addition, adding $\mathrm{Mn}^{2+}$ reduced the phosphate coating porosity and improved surface coverage which led to an enhanced corrosion resistance. ${ }^{22}$
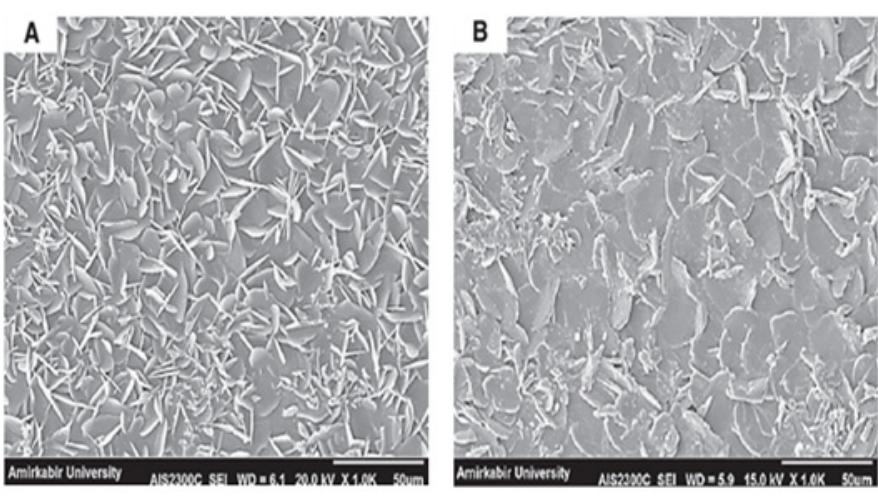

Figure 4 SEMs of the samples treated in phosphate bath (A) without $\mathrm{Mn}^{2+}$ and (B) containing $\mathrm{Mn}^{2+} .22$

Molybdenum addition: Molybdenum could be considered one of the promising compounds to be incorporated into the phosphating bath. ${ }^{56}$ $\mathrm{Lin}^{56}$ reported that addition of $\mathrm{Mo}^{2+}$ resulted in a significant corrosion inhibition capability, almost close to that of chromate conversion coatings. They attributed this enhancement in corrosion resistance to the modified morphology of coating from needle-like to fine flakeshaped structure and to the increase in coating compactness, coating mass and coverage (Figure 4). ${ }^{56}$

Nano-silica addition: Sheng ${ }^{24}$ has recently introduced $\mathrm{SiO}_{2}$ nanoparticles in the phosphating bath as a novel accelerator. They demonstrated that with addition of these nano-particles the crystal structure of the phosphate conversion coating was refined, and the coating weight was increased resulting in a much better corrosion prevention capability. In addition, the presence of $\mathrm{SiO}_{2}$ nanoparticles influenced the preferential orientation of the phosphate crystals and the coating morphology Sheng. ${ }^{24}$ Nano-silica in the phosphating bath acts as a catalyst for the formation of more dense and compact phosphate coating on the rebar surface. ${ }^{11}$ Addition of nano-silica also ensured about $11 \%$ increase in bond strength between concrete and reinforcement. ${ }^{11}$ In addition, nano-silica modified zinc phosphate coated steel showed the lowest corrosion currents $\left(\sim 0.375 \mu \mathrm{A} . \mathrm{cm}^{-2}\right)$ when compared to nano-silica free coatings $\left(\sim 0.535 \mu \mathrm{A} . \mathrm{cm}^{-2}\right) .{ }^{11}$ This, according to Manna ${ }^{11}$ can be explained by the presence of more zincbearing phosphate compound in this phosphate coating as zinc-bearing phosphate compounds are less reactive to aggressive chloride solution and better insulating capability against charge transfer than the ironbearing phosphate compounds. ${ }^{11}$ The dissolution rate of iron from steel surface is slower for nano-silica containing phosphate solution because nano silica is adsorbed on the steel surface and thereby hinders the dissolution of iron. ${ }^{11}$ Finally, It is worth mentioning that in the automotive industries, the phosphate conversion coating process is usually performed in a trication bath, which is mainly composed of $\mathrm{Zn}^{2+}, \mathrm{Ni}^{2+}$, and $\mathrm{Mn}^{2+}$ ions. ${ }^{57,14}$ This tri-cations zinc phosphating bath led to a significant refinement of crystals, as shown in Figure 5. ${ }^{14}$ 

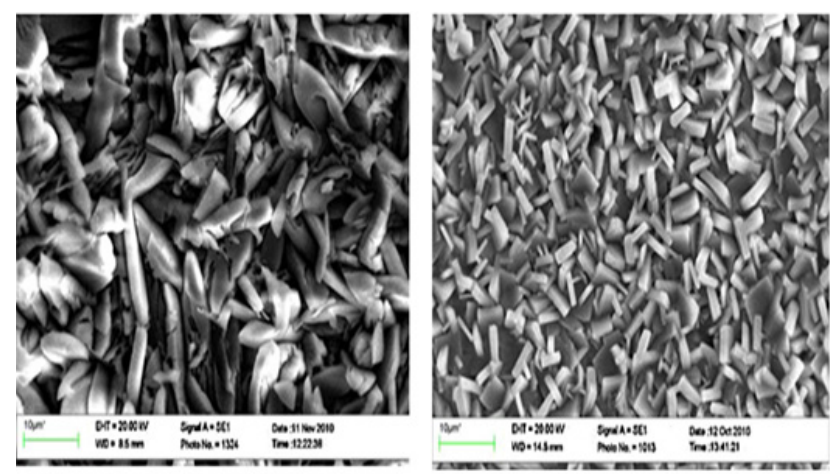

Figure 5 SEM images of the crystalline phosphate coatings on the carbon steel surface $\mathrm{PZn}$ (left) and $\mathrm{PZnNiMn}$ (right).

Sludge formation: Dissolved $\mathrm{Fe}^{3+}$ ions from the pickling reaction are precipated as iron (III) phosphate as in the following reaction: ${ }^{30}$

$$
\mathrm{Fe}^{3+}+\mathrm{H}_{2} \mathrm{PO}_{4}^{-} \rightarrow \mathrm{FePO}_{4}(\text { sludge })+2 \mathrm{H}^{+}
$$

The created sludge in the process is normally filtered out from the solution utilizing some sort of filter media or equipment (Figure 5). ${ }^{30}$ Phosphate sludge is a by-product that could be suitable for ceramics manufacturing. However, because of shortage of alumina and silica, it should be enriched with aluminosilicates such as clays. ${ }^{58}$ Caponero \& Tenorio ${ }^{59}$ suggested using this sludge in cement clinker. Their results showed no damage to the clinkerization process with an addition of up to $7.0 \%$ sludge. In addition, According to Ucaroglu \& Talinli, ${ }^{60}$ the phosphate coating sludge after being treated by solidification/ stabilization can be used in a matrix of Portland cement. Baldy ${ }^{61}$ also studied the possibility of reclaiming this sludge to a zinc-phosphate replenishment solution and other useful products.

\section{Conclusion}

This paper was an attempt to briefly review effects of some additives such as alkali metal ions and $\mathrm{SiO}_{2}$ nanoparticles on zinc phosphate coating properties. Addition of certain compounds such as metal ions or nanoparticles to the zinc phosphating bath led to improvements in the zinc coating performance in terms of reinforcement corrosion resistance and the bond strength between concrete and steel. Further studies on the chemical stability of the modified zinc phosphate coatings on reinforcement are highly recommended. Long term tests when these coatings are exposed to chloride ions are also recommended.

\section{Acknowledgments}

None.

\section{Conflicts of interest}

Author declares that there is no conflict of interest.

\section{References}

1. Neville A. Chloride attack of reinforced concrete: an overview. Materials and Structures. 1995;28:63-70.

2. Verbeck GJ. Mechanisms of corrosion in concrete, in Corrosion of Metals in Concrete, SP-49. American Concrete Institute. 1975;49:21-38.

3. Poursaee A. Corrosion protection methods of steel in concrete. In Corrosion of Steel in Concrete Structures edited by Poursaee, A Elsevier Ltd; 2016.
4. Bertolini L, Elsener B, Pedeferri P, et al. Corrosion of Steel in Concrete: Prevention, Diagnosis, Repair. 2nd ed. Wiley-VCH Verlag GmbH \& Co. KGaA, Boschstr: Weinheim, Germany; 2003.

5. Elsener B. Corrosion Inhibitors for steel in concrete-state of the art report. Construction and Building materials. 2001;22(4):609-622.

6. Carmona J, Garcés P, Climent MA. Efficiency of a conductive cementbased anodic system for the application of cathodic protection, cathodic prevention and electrochemical chloride extraction to control corrosion in reinforced concrete structures. Corros Sci. 2015;96:102-111.

7. Hansson CM. Corrosion of stainless steel in concrete. In Corrosion of Steel in Concrete Structures edited by Poursaee A, Elsevier Ltd; 2016. 312 p.

8. Ormellese M, Bolzoni F, Goidanich S, et al. Corrosion inhibitors in reinforced concrete structures Part 3 - migration of inhibitors into concrete. Corrosion Engineering, Science and Technology. 2011;46(4):334-339.

9. Elshami AA, Bonnet S, Khelidj A, et al. Novel anticorrosive zinc phosphate coating for corrosion prevention of reinforced concrete. European Journal of Environmental and Civil Engineering; 2016.

10. Simescu F, Idrissi H. Effect of zinc phosphate chemical conversion coating on corrosion behaviour of mild steel in alkaline medium: protection of rebars in reinforced concrete. Science and Technology of Advanced Materials. 2008;9(4)

11. Manna M, Shah A, Kulkarni SV. Development of phosphate coating on the surface of TMT rebar: an option to study the effect of n-SiO2 as an additive. Ironmaking and Steelmaking. 2016;44(9):666-675.

12. Jalili MM, Moradian S, Hosseinpour D. The use of inorganic conversion coatings to enhance the corrosion resistance of reinforcement and the bond strength at the rebar/concrete. Construction and Building Materials. 2009;23(1):233-238.

13. Simescu F, Idrissi H. Corrosion behaviour in alkaline medium of zinc phosphate coated steel obtained by cathodic electrochemical treatement. Corrosion Science. 2009;51(4):833-840.

14. Girciene O, Ramanauskas R, Gudaviciute L, et al. Formation of conversion $\mathrm{Zn}-\mathrm{Ni}-\mathrm{Mn}$ phosphate coatings on steel and corrosion behaviour of phosphated specimens in a chloride-contaminated alkaline solution. Chemiji. 2013;24(3):182-189.

15. Zarras P, Stenger-Smith JD. Smart Inorganic and Organic Pretreatment Coatings for the Inhibition of Corrosion on Metals/Alloys. Intelligent Coatings for Corrosion Control. 2015:59-91.

16. Weldon DG. Failure Analysis of Paints and Coatings. John Wiley \& Sons, Ltd; 2009.

17. Tamilselvi M, Kamaraj P, Arthanareeswari M, et al. Development of nano $\mathrm{SiO} 2$ incorporated nano zinc phosphate coatings on mild steel. Applied Surface Science. 2015;332:12-21

18. Fang F, Jiang JH, Tan SY, et al. Characteristics of a fast low-temperature zinc phosphating coating accelerated by an ECO-friendly hydroxylamine sulfate. Surface and Coatings Technology. 2010;204(15):2381-2385.

19. Harris DR, Casey P. Formulating Surface Coatings. In Active Protective Coatings: New-Generation Coatings for Metals, edited by Anthony E Hughes AE Mol, JMC Zhelukevich, ML Buchheit RG, Springer Series in Materials Science; 2016.

20. Grigoriev D. Anticorrosion Coatings with Self Recovering Ability Based on Damage Triggered Micro- and Nanocontainers. In: Intelligent Coatings for Corrosion Control edited by Tiwari A, Butterworth-Heinemann; 2015. 283-333 p.

21. Zeng R, Lan Z, Kong L, et al. Characterization of calcium-modified zinc phosphate conversion coatings and their influences on corrosion resistance of AZ31 alloy. Surface and Coatings Technology. 2011;205(11):3347-3355. 
22. Rezaee N, Attar MM, Ramezanzadeh B. Studying corrosion performance, microstructure and adhesion properties of a room temperature zinc phosphate conversion coating containing Mn2+ on mild steel. Surface and Coatings Technology. 2013;236:361-367.

23. Zimmermann D, Munoz AG, Schultze JW. Microscopic local elements in the phosphating process. Electrochimica Acta. 2003;48(2022):3267-3277.

24. Sheng M, Wang Y, Zhong Q, et al. The effects of nano-SiO2 additive on the zinc phosphating of carbon steel. Surface and Coatings Technology. 2011;205(11):3455-3460.

25. Bikulcius G, Girciene O, Martusiene A, et al. The Corrosion Behaviour of Electrochemical Zn Coated with Conversion Chromate and Phosphate Films in Concrete. Transactions of the IMF. 2002;80(4):113-115.

26. Bikulcius G, Girciene O, Burokas V. Corrosion Behavior in Alkaline Media of Steel with Various Conversion Coatings in Concrete. Russian Journal of Applied Chemistry. 2003;76(11):1759-1763.

27. Al-Swaidani AM, Al-Hassan A, Hamed H, et al. Study of corrosion behavior of reinforcing steel treated by the phophating method in a simulated concrete pore (SCP) solution. Magazine of Bassel el-Assad for Engineering Sciences. 2004;20:61-87.

28. Freeman DB. Phosphating and Metal Pre-Treatment. WoodheadFaulkner: Cambridge, UK; 1986.

29. Rahimi SH, Potrekar R, Dutta NK, et al. Anticorrosive interfacial coatings for metallic substrates. Surface Innovations. 2013;1(2):112-137.

30. Donofrio J. Zinc phosphating. Metal finishing; 2010. 40-56 p.

31. Kunst H. Metals, Surface Treatment, Encyclopedia of industrial chemistry. Wiley-VCH Verlag GmbH \& Co. KGaA: Weinheim; 2012.

32. Ogle K, Buchheit RG. Conversion Coatings, Corrosion Protection. Encyclopedia in electrochemistry; 2007.

33. Weng D, Jokiel P, Uebleis A, et al. Corrosion and protection characteristics of zinc and manganese phosphate coatings. Surface and Coaings Technology. 1997;88(1-3):147-156.

34. Ogle K, Tomandl A, Meddahi N, et al. The alkaline stability of phosphate coatings I: ICP atomic emission spectroelectrochemistry. Corrosion Science. 2004;46(4):979-995.

35. TomandlA, Wolpers M, Ogle K. The alkaline stability of phosphate coatings II: in situ Raman spectroscopy. Corrosion Science. 2004;46(4):997-1011.

36. Shoeib M, Farouk M, Hanna F. Metal Finishing. 1997;95:62.

37. Shibli SMA, Chacko F. Development of nano TiO2-incorporated phosphate coatings on hot dip zinc surface for good paintability and corrosion resistance. Appl Surf Sci. 2011;257(7):3111-3117.

38. Tamilselvi M, Kamaraj P, Arthanareeswari M, et al. Nano Zinc Phosphate Coatings for Enhanced Corrosion Resistance of Mild Steel. Applied Surface Science. 2014;327:218-225.

39. Shibli SMA, Chacko F. Development of nano CeO2-incorporated high performance hot-dip zinc coating. Surface and Coating Technology. 2008;202(20):4971-4975.

40. $\mathrm{Su} \mathrm{HY,} \mathrm{Lin} \mathrm{CS.} \mathrm{Effect} \mathrm{of} \mathrm{additives} \mathrm{on} \mathrm{the} \mathrm{properties} \mathrm{of} \mathrm{phosphate}$ conversion coating on electrogalvanized steel sheet. Corrosion Science. 2014;83:137-146.

41. Al-Swaidani AM. Unpublished data; 2017.

42. Panossian Z. Phosphating of Steel for Cold Forming Processes. In: Encyclopedia of Tribology edited by Wang QJ and Chung YW, Springer; 2013.
43. Sandu AV, Coddet C, Bejinariu C. Study on the chemical deposition on steel of zinc phosphate with other metallic cations and hexamethilen tetramine: I. Preparation and structural and chemical characterization. Chemistry Magazine. 2012;63(4):401-406.

44. Tegehall PE, Vannerberg NG. Nucleation and formation of zinc phosphate conversion coating on cold-rolled steel. Corrosion Science. 1991;32(56):635-652.

45. Paatsch W, Kautek W, Sahre M. Trans Inst Met Finish. 1997;75(6):216.

46. Girciene O, Ramanauskas R, Burokas V, et al. Formation of Phosphate Coatings on Steel and Corrosion Performance of Phosphated Specimens in Alkaline Solutions. Transactions of the IMF. 2004;82(5-6):137-140.

47. Satoh N. Effects of heavy metal additions and crystal modification on the zinc phosphating of electrogalvanized steel sheet. Surf Coat Technol. 1987;30(2):171-181.

48. Kulinich SA, Akhtar AS. On Conversion Coating Treatments to Replace Chromating for Al Alloys: Recent Developments and Possible Future Directions. Russian Journal of Non-Ferrous Metals. 2012;53(2):176-203.

49. Bhar GN, Debnath NC, Roy S. Effects of calcium ions on the morphology and corrosion resistance of zinc-phosphated steel. Surface and Coatings Technology. 1988;35(1-2):171-179.

50. Kripps WP. Metals Handbook. 9th ed. Ohio: American Society of Materials, USA; 1987.

51. Kouisnia L, Azzia M, Zertoubia M, et al. Phosphate coatings on magnesium alloy AM60 part 1: study of the formation and the growth of zinc phosphate films. Surface and Coatings Technology. 2004;185(1):58-67.

52. Zimmermann D, Munoz AG, Schultze JW. Formation of Zn-Ni alloys in the phosphating of $\mathrm{Zn}$ layers. Surface and Coating Technology. 2005;197(2-3):260-269.

53. Abdalla K, Rahmat A, Azizan A. Effect of copper (II) acetate pretreatment on zinc phosphate coating morphology and corrosion resistance. Journal of Coatings Technology and Research. 2013;10(1):133-139.

54. Leoni M, Fame G, Grimaldi R, et al. Nonmetallic conducting coatings: Properties and behaviour of iron and iron-copper phosphate coatings. Werkstoffe und Korrosion. 1986;3(8):463-470.

55. Perekhrest NA, Pimenova KN, Litovchenko VD, et al. Zashchita Metallov. 1992;28(1):134.

56. Lin BI, Lu JT, Kong G, et al. Growth and corrosion resistance of molybdate modified zinc phosphate conversion coatings on hot-dip galvanized steel. Transactions of Nonferrous Metals Society of China. 2007;17:755-761.

57. Oh JE, Kim YH. The corrosion resistance characteristics of $\mathrm{Ni}, \mathrm{Mn}$, and $\mathrm{Zn}$ phosphates in automotive body panel coatings. Ind Eng Chem. 2012;18(3):1082-1087.

58. Loutou M, Hajjaji M, Mansori M, et al. Heated blends of clay and phosphate sludge: Microstructure andphysical properties. Journal of Asian Ceramic Societies. 2015;177:169-176.

59. Caponero J, Tenorio JAS. Laboratory testing of the use of phosphatecoating sludge in cement clinker. Resources, Conservation and Recycling. 2000;29(3):169-179.

60. Ucaroglu S, Ilhan Talinli I. Recovery and safer disposal of phosphate coating sludge by solidification/stabilization. Journal of Environmental Management. 2012;105:131-137.

61. Baldy CJ. Recycling Zinc Phosphate Sludge Conclusion. Metal Finishing; 1996. 23-24 p. 